\title{
lauaretê, Cachoeira das Onças [Jaguar Waterfalls]
}

\section{Available at http://www.youtube.com/watch?v=X4Lyq9UwBAw}

2006, $48 \mathrm{~min}$

Film directed by Vincent Carelli

Produced by IPHAN - Institute of Historical and Artistic Heritage and Video nas Aldeias.

Anthropological consultants: Geraldo Andrello and Ana Gita de Oliveira. The film was produced in 2006 as part of the Registration Process of Iauaretê, Cachoeira das Onças [Jaguar Waterfalls], municipality of São Gabriel da Cachoeira, in the Upper Rio Negro. This sacred place was the first site to be inscribed in the "Book of Places" of Brazilian Immaterial Cultural Heritage. In addition to subsidizing the inclusion of these elements into the listing process, the film features the mythical account of the origin of humanity, which the Tariano Indians attribute to the stones of Iauaretê falls. It also shows some of the activities to safeguard the site, such as the reconstruction of a large hut and the successful attempt to retrieve ritual objects that had been stored for many years in a museum in Manaus.

IPHAN and the Ministry of Culture more recently began to support a large bi-national Brazilian-Colombian project intended to retrace the trajectory of the tukanoan ancestral anaconda-canoe, mapping all the relevant places along the Rio Negro between Manaus and São Gabriel da Cachoeira, and from there to the Ipanoré Falls on the middle Uaupés from where humanity emerged according to the vision of tukanoan Indians. This project is now underway with a first part of the journey having been undertaken in February 2013, with the participation of Tukano, Desana, Pira-Tapuia, Tuyuka, Bará and Makuna indigenous specialists. Images and narratives are being produced with the aim of editing a new video documentary on the theme of the simultaneous appearance and differentiation of regional landscape and humanity. 